\title{
UM FIO DE VOZ TECENDO BIOGRAFIAS FICCIONAIS
}

\author{
Maria Zeneide de Macedo Melo Jorge ${ }^{1}$ \\ Rita de Cássia Silva Dionísio²
}

\begin{abstract}
Resumo: Este trabalho tem como objetivo apresentar uma leitura da obra Vésperas da escritora contemporânea Adriana Lunardi. A autora através de um olhar inovador conduziu as personagens escritoras, poetas e romancistas, nascidas no século XIX e XX, para reencenar em uma era pós-moderna: Virgínia Woolf, Dorothy Parker, Colette, Katharine Mansfield, Sylvia Plath, Zelda Fitzgerald, Ana Cristina César, Júlia da Costa e Clarice Lispector. No desenrolar da narrativa é pertinente esclarecer que o narrador chama a nossa atenção para a importância da estrutura dos contos, aproximando as mulheres escritoras das suas produções artísticas, revelando o encontro dessas personagens com a morte. Faz isso, tentando reproduzir a realidade dos fatos narrados e também para tornar as cenas narradas mais próximas de um realismo.
\end{abstract}

Palavras-Chave: Vésperas, Adriana Lunardi, Biografia ficcional.

Resumen: Este trabajo tiene como objetivo presentar una lectura de la obra Vísperas de la escritora contemporánea Adriana Lunardi. El autor a través de una mirada innovadora llevó a los personajes escritores, poetas y novelistas, nacidos en los siglos XIX y XX, para recrear en una era posmoderna: Virginia Woolf, Dorothy Parker, Colette, Katharine Mansfield, Sylvia Plath, Zelda Fitzgerald, Ana Cristina César, Julia da Costa y Clarice Lispector. A lo largo de la narración es útil recordar que el narrador nos llama la atención sobre la importancia de la estructura de las historias, acercándose a las escritoras de sus producciones artísticas, revelando estos personajes se enfrentan con la muerte. Hazlo, tratando de reproducir la realidad de los hechos, así como para hacer las escenas narradas cercano al realismo.

Palabras-Clave: Vísperas, Adriana Lunardi, Biografía ficticia.

1 Mestre pelo Programa de Pós-Graduação em Letras/Estudos Literários da Universidade Estadual de Montes Claros (UNIMONTES). Endereço eletrônico: maria_zeneide@ig.com.br.

2 Docente da Graduação em Letras e do Programa de Pós-Graduação em Letras/Estudos Literários da UNIMONTES. Pesquisadora membro do GT Vertentes do Insólito Ficcional da ANPOLL. Integra o Corpo Docente do Mestrado Profissional em Letras em Rede Nacional (PROFLETRAS), constituído pela Rede Nacional de Instituições de Ensino Superior. Endereço eletrônico: cassiadionisio@hotmail.com. 
A obra Vésperas (2002), objeto deste artigo, tem como tema principal a vida de mulheres escritoras que marcaram o contexto histórico com suas produções literárias. A escritora Adriana Lunardi ${ }^{3}$ nos apresenta, nesta obra, a vida dessas mulheres, poetas e romancistas, nascidas nos séculos XIX e XX: Virginia Woolf, Dorothy Parker, Colette, Katharine Mansfield, Sylvia Plath, Zelda Fitzgerald, Ana Cristina César, Júlia da Costa e Clarice Lispector.

Podemos dizer que, na obra Vésperas, Adriana Lunardi transformou a vida das personalidades históricas em matéria ficcionalizada. Para tanto, no final do livro (na parte "Sobre as personagens”), a autora faz uma espécie de minibiografia dessas mulheres, citando a profissão, o modo como morreram, suas principais obras e os apelidos das autoras protagonistas. Além desses aspectos, a autora procurou inovar os fatos históricos, dando uma nova roupagem a essas biografias em seus contos, entrelaçando informações da vivência social dessas escritoras, possibilitando, de certa maneira, uma abertura para as reflexões sobre o discurso de uma biografia ficcionalizada.

A obra contém nove biografias convertidas em matéria ficcional. Nelas, a autora circunscreve o entrelaçamento do ficcional e do biográfico, tematizando a problemática da morte e da representação literária de autoria feminina. Na verdade, Adriana Lunardi arquiteta, em sua ficção, biografias de mulheres escritoras que ultrapassam os limites do ficcional e do biográfico. Nesse espaço, ela abre, nas dobras do texto literário, fendas, possibilitando um lugar no qual se (re)cria um entre-lugar ${ }^{4}$ habitado pela autora e pelas escritoras artistas, onde muitas vozes se encontram e ressoam sucessivas formas de representação. A partir dessas repre-

3 Adriana Lunardi nasceu em 1964, em Santa Catarina, na cidade de Xaxim; atualmente, reside no Rio de Janeiro e trabalha escrevendo roteiros para o programa Expedições, exibido pela TV Cultura e pela TVE Brasil. Escreveu seu primeiro livro de contos, As meninas da Torre Helsinque, em 1996, seguido de Vésperas (2002), Corpo estranho (2006) e A vendedora de fósforos (2011). A autora de Vésperas em 1979 mudou-se para Santa Maria, onde cursou Comunicação Social na Universidade Federal de Santa Maria (UFSM). A autora possui ainda textos publicados em antologias, como O livro das mulheres, de 2000, e Pata maldita, de 2001. (Informações retiradas de: LUNARDI, s.d.).

4 Para Silviano Santiago, em Uma literatura nos trópicos: ensaio sobre dependência cultural (2000), o entrelugar pode representar um local de descentramento e heterogeneidade atribuídos à cultura europeia. Em seus postulados, o autor afirma que a "América Latina institui seu lugar no mapa da civilização ocidental, graças ao movimento de desvio da norma, ativo e destruidor, que transfigura os elementos feitos e imutáveis que os europeus exportavam para o Novo Mundo” (SANTIAGO, 2000, p. 16). Para Homi K. Bhabha (1998), o entrelugar refere-se a uma zona de interstícios, uma fronteira de movimentos que fornece "terreno para a elaboração de estratégia de subjetivação — singular ou coletiva que dão início a novos signos de identidade”. Um lócus onde se formam sujeitos, "nos excedentes da soma das 'partes' da diferença (geralmente expressas como raça/classe/gênero, etc.)” (BHABHA, 1998, p. 19-20). 
Pontos de Interrogação, v. 3, n. 1, jan./jul. 2013

Revista do Programa de Pós-Graduação em Crítica Cultural

Universidade do Estado da Bahia (UNEB), Campus II - Alagoinhas - BA

sentações, aceita-se que a mulher escritora, segundo Adriana Lunardi, espie ao seu redor, testando a "invisibilidade abraçando um menino sem sentir o volume do seu corpo. Meus braços o atravessam e encontram o nada. Na eternidade não há peso, nem leveza [...]” (LUNARDI, 2002, p. 52) que possa equilibrar o enigma do tecido textual.

As vozes das personagens da obra Vésperas configuram-se como um discurso de autoria feminina que, em outras épocas, foi, por muito tempo, camuflado e silenciado. A partir das reflexões sobre gênero, consolidadas na pós-modernidade, a escrita de autoria feminina, considerada insignificante, anônima e indiferente aos olhos dos homens, conquista maior espaço no campo social. É uma escrita que ganha visibilidade na história, assim como no contexto literário lunardiano, cujo discurso nasce centrado na biografia de mulheres escritoras.

Com relação ao título da obra, Vésperas, segundo o Dicionário Houaiss, é uma palavra que se origina do latim, vespera ou vesperae, que significa “a tarde, ao cerrar da noite”, que, por sua vez, deriva de vésper, vésperis ou vésperus, que quer dizer “estrela Vésper, estrela ou planeta de Vênus, quando aparece, à tarde; tarde, o poente, o ocidente” (HOUAISS; VILLAR, 2004, p. 2853). Por outro lado, véspera significa a oração que se destina a agradecer a Deus por todas as graças recebidas e pelo bem realizado no dia. Além disso, lembra ainda a obra da redenção de Cristo e a sua última ceia, na qual Ele deixou o memorial da salvação, partindo do simbolismo da luz e da escuridão. Junto às laudes (que são horas litúrgicas ou louvores matinais), véspera é também um dos polos do ofício realizado no quotidiano, uma espécie de liturgia das horas das quais os cristãos, insistentemente, são convidados a celebrar (HOUAISS; VILLAR, 2004, p. 2853).

A imagem da capa da obra Vésperas lembra a moldura de um quadro que se entrelaça no jogo textual, formando uma espécie de paratexto na obra. Gérard Genette, em Paratextos editoriais (2009), propõe um conceito para a palavra paratexto. Segundo o autor, paratexto pode ser designado como um conjunto de textos que, somado ao texto principal, compõe um livro: título, subtítulo, nome de autor, epígrafes, prefácios, dedicatórias, notas, notícias de jornal, entrevistas, resenhas, resumos biográficos, entre outros (GENETTE, 2009, p. 10). Esse jogo do texto que se encaixa em outros textos, estabelecendo paratextos no texto principal, interliga-se em uma rede discursiva engendrada pela história de mulheres artistas. Na obra Vésperas, os paratextos podem ser caracterizados como uma relação entre as escrituras das 
mulheres, mas também pode se relacionar à pintura de um quadro, pois se percebe que a obra é cercada de aparatos, começando pelo formato da capa até o último conto, “Sonhadora”, que fecha a obra, no qual a protagonista pinta em painéis a história da sua vida, antes da sua morte.

A obra em análise apresenta duas epígrafes que constituem o ponto de partida para as nossas reflexões. Gérard Genette (2099, p. 141), referindo-se aos paratextos, afirma que "a epígrafe é sempre um gesto mudo cuja interpretação fica a cargo do leitor”. A primeira epígrafe, de Clarice Lispector (apud LUNARDI, 2002, p. 9), diz: "Espero viver sempre às vésperas. E não no dia”. Essas palavras, de certa forma, poderiam ser entendidas, literalmente, como se viver às vésperas da morte fosse melhor do que viver o dia, porque viver o dia estaria mais próximo do fim, ou seja, das horas da morte.

Mas isso seria, na verdade, uma forma de conceber a morte das mulheres escritoras. Quando Adriana Lunardi tomou de empréstimo as palavras de Clarice Lispector, evidencianos que, talvez, existisse, nas vésperas, um ponto de partida entre a vida e a morte. Entretanto, existem outros pontos; o da linguagem, por exemplo, no qual se engendram os mistérios subjetivos que não foram e não serão, no entanto, desvendados pelas autoras. Zelda, por exemplo: "se desembaraça das amarras com a agilidade sutil de uma borboleta a sustentar o voo. Para ela, não era cedo, nem tarde. Era a hora” (LUNARDI, 2002, p. 102). A escrita parece, nesse momento, tomar outro rumo, o do inacabado, que se embaraça como uma espiral; isso pode frustrar o leitor, que esperava que o mistério da morte fosse desvendado, mas tal mistério não o pode ser porque, ideologicamente, as escritoras contemplam a alquimia da linguagem literária.

A pesquisadora Telma Borges, em "Literatura brasileira — modernidade e tendências contemporâneas” (2004), aponta uma possibilidade de leitura dos textos de alguns autores, entre eles, os de Adriana Lunardi, que contribuíram para a literatura brasileira do último século e do atual. Ela afirma que:

Para Adriana Lunardi, a morte é condição para o progresso e para a vida que se fixa através da linguagem, da literatura. Vale-se, portanto, dessa condição inaugurando, por meio da morte, uma tradição cuja relação parece-nos muito próxima daquela representada pela personagem do último conto. A morte deixa de ser, portanto, um fim para se constituir como possibilidade de renascer através da palavra, o ouro alquímico da literatura (BORGES, 2004, p. 60). 
Pontos de Interrogação, v. 3, n. 1, jan./jul. 2013

Revista do Programa de Pós-Graduação em Crítica Cultural

Universidade do Estado da Bahia (UNEB), Campus II - Alagoinhas - BA

Borges atenta para o fato de que a morte não é o fim, é uma possibilidade para um novo começo, seja este começo marcado pela sutileza da linguagem sobre a morte ou sobre o enigma paradoxal que envolve o pós-morte das personagens. Esse enigma paradoxal está presente em todo o texto lunardiano, e pode ser também observado na segunda epígrafe de Vésperas, que é um poema de Emily Dickinson (1830-1886):

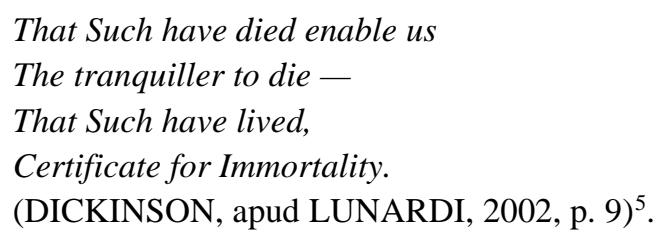

Nos fragmentos do poema em questão, de Emily Dickinson, pode-se perceber que o sujeito poético parece acreditar na possibilidade de que, além deste mundo, existe outro no qual seremos meramente imortais. Parece que Adriana Lunardi, quando escreveu a sua obra, certificou-se dessas possibilidades, convidando, cuidadosamente, cada uma dessas escritoras para viver as eternas Vésperas.

Com relação à obra de Emily Dickinson, Luis André Nepomuceno, em seu texto "O eu e o mundo nas cartas de Emily Dickinson” (2011), em que avalia o papel autobiográfico e ficcional da construção de um sujeito identitário no epistolário de Emily Dickinson, afirma que as cartas desempenharam um importante papel em sua vida; elas se tornaram um meio “de comunicação com o mundo, levando e trazendo notícias, ou mesmo desempenhando a função poética, naquela prática rotineira de construção de uma identidade autobiográfica, em que projeções de ficção e elementos da realidade se completam” (NEPOMUCENO, 2011, p. 175). Emily Dickinson viveu na solidão da casa paterna, em Amherst, Massachusetts; conforme Luis André Nepomuceno (2011, p. 175):

Nas cartas procurou o exercício da interlocução como atividade literária. Seu epistolário revela a escritora na prática de sua função poética, a compor elementos de ficção que dialogam com os fatos quotidianos da vida, ampliando significados e traçando um perfil autobiográfico, em que vida e expressão literária coexistem e se misturam, sem que se possa traçar fronteiras e limites entre eles.

Luis André Nepomuceno (2011, p. 173) aponta ainda que Emily Dickinson “parece ter cultivado o gosto pela obscuridade e pela falta de regras — dois valores de estima à opinião

5 "Que tal ter morrido permite-nos / O Tranquilizador a morrer / Que tal ter vivido, / Certificado para a imortalidade” (tradução nossa). 
romântica. [...] Também, ela deu vazão às coisas da natureza em detrimento das regras, e mostrou-se consciente disso, especialmente nas cartas” que escreveu desde 1842, quando tinha apenas 11 anos de idade: “até o fim da vida, em 1886: seu epistolário compõe um rico acervo de 1046 cartas a quase 100 interlocutores diferentes (na edição de Johnson, 1960), verdadeiro patrimônio literário, face à consciência crítica e poética da autora” (NEPOMUCENO, 2011, p. 160).

É pertinente esclarecer que os contos da obra Vésperas encontram-se interligados por uma espécie de fio que conduz as personagens para um labirinto metafórico da linguagem ficcionalizada. Nesse labirinto, o fio interliga os elementos simbólicos, como as cartas, a poesia e a memória, que fazem parte do mundo da construção das personagens narradas. Na verdade, esse fio com o qual a autora alinhava o texto desdobra-se em vários outros, que sustentam o emaranhado de elementos que se desvencilham na narrativa, contribuindo para um jogo enigmático não somente de vida e morte, mas também conduzindo as escritoras ao caminho da metaficcionalidade.

A propósito dos elementos interligados estrategicamente, nota-se que a obra Vésperas aborda, na capa da primeira edição brasileira, a imagem de uma mulher aparentando um ar calmo e sereno, enunciando uma leve brisa mansa que faz soprar em seu rosto a suavidade dos fios de cabelos. A cabeça levemente inclinada para baixo; na face, a ausência de luz encobre a direção do seu olhar. Nas mãos, uma espécie de prancheta para, talvez, registrar a imagem que se vê ao fundo. Se não fosse pelo contraste das cores branco e preto, diríamos que a imagem remete a uma natureza bucólica, que exalta a tranquilidade e a beleza da vida campestre.

Percebe-se que a descrição da imagem da capa pode ser observada por uma abertura ovular. A capa se sobrepõe à imagem que fica ao fundo, passando a formar um conjunto de moldura/capa/imagem/figura que irá proporcionar ao livro um aspecto de livro/quadro para apresentar, na escritura, a história das mulheres lunardianas. Essa capa poderia também ser vista por outro ângulo, desdobrando-se em uma espécie de quadro/livro para que as personagens pudessem ser representadas como figuras de uma pintura, como sugere o último conto da obra, no qual a protagonista, ao invés de escrever, pinta a história de sua vida.

A capa permite ainda observar que a imagem da mulher encontra-se de perfil, ligeiramente afastada do centro, seja por uma questão de melhor estética, seja para dar melhor visi- 
Pontos de Interrogação, v. 3, n. 1, jan./jul. 2013

Revista do Programa de Pós-Graduação em Crítica Cultural

Universidade do Estado da Bahia (UNEB), Campus II - Alagoinhas - BA

bilidade à paisagem. Uma paisagem com tonalidade cinza, sobressaindo-se as cores clara e escura. Segundo Adenize Franco, em “Às Vésperas do fim: um passeio pela narrativa contemporânea de Adriana Lunardi” (2006), que realiza um estudo sobre a literatura produzida por mulheres para melhor compreender as divergências entre gêneros, a capa da obra Vésperas apresenta um:

Fundo branco, imagem negra. Contrastes entre o claro e o escuro, a vida e a morte, o começo do fim. Semelhante a um fragmentário barroco [...] retrata uma mulher — num plano próximo — com um livro ou caderno em mãos, com o rosto encoberto pela sombra sem se poder visualizar a direção do seu olhar. Ao fundo - num plano distante - um campo. Mesmo com a face encoberta, essa mulher transmite uma certa angústia e por essa vaga impressão deduz-se que seu pensamento está longínquo (FRANCO, 2006, p. 98).

Além desses aspectos, nota-se, na imagem, a forma curva, que dá a impressão de ultrapassar os limites da moldura e da imagem que margeiam a contracapa. Ao fundo, em recuo, uma claridade enuncia um plano difuso, transmitindo um vazio angustiante na infinitude natural. O contraste do preto e do branco ofusca a luz, sombreando a curva que margeia a capa, e parece convidar o leitor a penetrar na trama e a desvendar o enigma narrativo. Com relação às cores, para Jean Chevalier e Alain Gheerbrant, elas podem ser interpretadas de várias maneiras; o branco, por exemplo, é a cor dos mortos e a cor que afasta os mortos, podendo possuir um poder curativo. Já o “preto, cor da noite, é a cor também das provas, do sofrimento, do mistério. Pode ser o abrigo do adversário que espreita...”6 (CHEVALIER; CHEERBRANT, 2005, p. 277).

Em um primeiro momento, percebe-se que o narrador, em "Ginny”, reside no substrato da realidade, uma vez que se apropria de dados verossímeis e retorna ao mundo do ficcional, pontilhando a narrativa de ecos biográficos. Nas palavras de Carla Rodrigues, em "Nove escritoras à beira da morte”: “Adriana faz um relato tão perfeito do suicídio da autora inglesa Virginia Woolf que a impressão é que se está diante de um documentário sobre a sua morte. Trata-se de pura literatura, [...]” (RODRIGUES, s.d. [online]), ou de confissões fictícias que poderiam perfeitamente levar o leitor menos desavisado a acreditar que a história contada

6 A cor branca, conforme Chevalier e Cheerbrant, pode indicar "a aurora; acima do branco, expandia-se o azul, para a manhã; abaixo do azul estava o amarelo, símbolo do pôr-do-sol; e acima dele, o preto, imagem da noite. Mais adiante, no mito, o branco entra em ação sob a forma de pérolas, e o azul sob a forma de turquesa" (CHEVALIER; CHEERBRANT, 2005, p. 276). 
passa-se no mundo real. O diálogo do narrador no processo narrativo conduz o leitor a uma grande simbologia linguística, propondo, sugestivamente, que se está diante de acontecimentos reais, ou seja, dentro do contexto ou da estrutura narrativa histórica relacionada ao mundo das escritoras. Para Adriana Lunardi, em entrevista a Rogério Pereira e Yasmin Taketani em o Rascunho:

\begin{abstract}
Nesse caso, temos que usar o disfarce, o drible, o despiste para parecer que é verdade o que estamos escrevendo. Mesmo quando se afirma tratar-se de um texto de ficção, o leitor procura fantasmas nas entrelinhas, lê entrevistas do autor e toma emprestado delas as razões e motivos de ele escrever o que escreve. De minha parte, eu jogo o jogo. O importante é conseguir o efeito de verdade que o texto produz. Assim, ao ter certas garantias “documentais”, o leitor relaxa, deixa-se levar por aquilo que ele atribui como sendo a parte ficcionalizada da escrita. No que, claro, pode estar bem enganado. Em Vésperas, lidei diretamente com essas falsas garantias: em geral, o que se lê como ficção é pura biografia, e vice-versa (LUNARDI, 2012 [online]).
\end{abstract}

O embaraço faz-se presente na narrativa, mas se nota uma sensibilidade artística nas entrelinhas do texto que marca o (des)compasso da transposição de vozes para a ficcionalidade, percebendo-se, portanto, que o efeito da linguagem biográfica ultrapassou o jogo da intertextualidade no discurso narrativo. Nesse contraste, a ressonância de vozes, que dá sustentabilidade e equilíbrio às personagens, atormentadas pelos lapsos de memória e de angústia, atribui como verossímil a parte ficcionalizada da escrita, na qual elas encontrarão o caminho da dupla face, na tessitura ficcional. No entanto, pode-se depreender, nesse jogo mimético, que: "Virginia tentou comprimidos e doutores tantas vezes quanto seus anos de vida, seis décadas quase completas. Havia épocas em que as vozes desapareciam, mas esses intervalos eram cada vez mais curtos e, ao voltar, pareciam estar sempre menos afinadas” (LUNARDI, 2002, p. 16).

A fronteira entre o biográfico e o ficcional é muito importante na obra lunardiana; podese dizer que é um dos recursos que dão sustentabilidade à narrativa. Funciona mais ou menos como uma espécie de pano de fundo para o foco narrativo principal, o qual é caracterizado como produção feminina das grandes escritoras-artistas. Elas teriam como representação a duplicidade de papeis; aliás, há entre elas uma trajetória muito parecida: o drama da morte, a frustração, a desilusão, o sentimento de culpa e a impossibilidade de comunicação são dramas sofridos pelas escritoras. Nesta obra, temos narradores bastante precavidos, uma vez que conseguem situar essas personagens como protagonistas, sem perder de vista o papel de escritoras-artista no contexto histórico. Mas é interessante ressaltar que eles participam do jogo da 
Pontos de Interrogação, v. 3, n. 1, jan./jul. 2013

Revista do Programa de Pós-Graduação em Crítica Cultural

Universidade do Estado da Bahia (UNEB), Campus II - Alagoinhas - BA

autora, provocando, às vezes, uma "babel de vozes” na face do texto, propondo que as escritoras assumam um duplo papel na narrativa, ou seja, podendo ser (con)fundidas com as versões originais de escritora ou de protagonista do texto. É nesse instante, portanto, que existe uma simulação no sentido de essas escritoras serem (re)duplicadas entre o espaço ficcional e o biográfico; parece que o leitor aprecia essa confusão e acha a história mais envolvente, como aponta Adriana Lunardi em o Rascunho:

Tendo a achar que o leitor aprecia a confusão entre o ficcional e o biográfico; se sente mais participativo ao ter margem de suspeição de que a história que está lendo foi vivida pelo autor. Parte disso vem de nossa relação problemática com a verdade, especialmente em nossa cultura ibérica, católica, onde simular é pecado. É como se o autobiográfico acrescentasse uma função exemplar à literatura, por isso o apreço maior pela coisa vivida do que à coisa simplesmente imaginada (LUNARDI, 2012 [online]).

Sabe-se que a mulher retorna para a superfície do texto lunardiano com um papel de dupla personalidade. Surge ora como uma criação habitando o texto ficcional, ora como uma mulher real habitando o texto biográfico. Mas é interessante notar que a mulher, como escritora, habitou as margens e os rodapés do contexto literário na historiografia. Já como personagens de ficção, essas mulheres, no entanto, não passavam de um fantasma, ou de uma mulher de papel ou ficcional que sempre (des)encanta o leitor no decorrer dos séculos. Por outro lado, elas podem ser também objetos da escritura, dirigirem e multiplicarem a herança familiar; nem por isso são elevadas à condição de autoridade preponderante no meio social. Elas terminam, com base na tradição patriarcal, transgredindo o sistema social, por comandarem o patrimônio e os costumes de uma sociedade marcada pelo poder arcaico vigente. Acabam sendo, na verdade, frutos de uma sociedade na qual todos os poderes e direitos eram depositados nas mãos do homem, cuja personalidade fálica e viril comandava os domínios da tradição burguesa secular.

Lembrando que os caminhos percorridos pelas mulheres ao longo dos séculos foram bastante árduos, a mulher escritora passa a ser renegada pelos homens e também pelos princípios criados por eles. São ainda, como diz Adriana Lunardi, "sem motivos grandiosos, o interior do átomo, o prego no alto da parede aferrado ao vazio da gaiola que se foi” (LUNARDI, 2002, p. 82). Para a mulher, restam apenas as marcas fincadas no profundo vazio da solidão, cujas memórias criaram raízes e abriram fendas no interior da escrita feminina para dialogar no plano subjetivo e da morte. No entanto, percebe-se que a morte circula no texto das mulhe- 
res escritoras como um agravante social da alma humana feminina, para preencher o vazio da opressão, da submissão, da angústia, da solidão e dos sonhos frustrados das escritoras. A morte, na verdade, é um ponto de interseção entre o espaço da escrita biográfica e o espaço da escrita ficcional, estando condicionada pela transitoriedade do tempo no universo feminino lunardiano. Pode-se dizer que, no texto, a morte surge, no plano real, como uma possível ressurreição; já no plano ficcional, habita a câmara mortuária, sendo reencarnação.

É nesse espaço literário subjetivo que a mulher lunardiana encontra-se, angustiada, percorrendo os caminhos enfadonhos da reclusão; sua vida é marcada pela loucura, pela velhice, pelo suicídio, pela cegueira e por doenças incuráveis, como o câncer e a tuberculose. Elas são amigavelmente tratadas pelos apelidos de infância nos contos, talvez para amenizar a dor e o sofrimento de crueldade que a vida reservou para elas. Estrategicamente, é essa a imagem de mulher que dialoga com os signos que estão presentes no texto literário, principalmente o signo da morte; notando-se ainda que a presença da arte e do ser artista está imbricada na própria nuance do texto, em consonância com a escrita de autoria feminina. Assim, é necessário lembrar que tanto o ficcional como o biográfico, os quais conduzem o foco narrativo, interrelacionam-se para produzir o efeito da verossimilhança na produção da escrita de autoria feminina em Vésperas.

As pesquisadoras Lúcia Castello Branco e Ruth Silviano Brandão, em A mulher escritora (2004), analisam, na literatura, o perfil feminino, e investigam a mulher como representação literária na ficção masculina e também como sujeitos de sua própria escrita. Segundo as autoras: “o texto literário é sempre confusão de vozes, babel de desejos, fascinante equívoco, lido como realidade [...] o texto é o lugar onde esses objetos se corporificam na materialidade dos significantes” (BRANCO, BRANDÃO, 2004, p. 11). No texto é que se engendram as vozes de subjetivação, pelas quais se ecoa a poesia, o romance e o conto. Podemos dizer que essas formas literárias se nutrem das relações de desejos, das angústias, da solidão, dos conflitos e das inquietações que latejam nas vozes do autor/narrador/personagens.

Muitas dessas tessituras ficcionais podem ser organizadas em um coro de vozes, as quais se entrelaçam como se fossem uma só voz representativa. Na obra de Adriana Lunardi, os narradores parecem apossar das vozes das mulheres escritoras para marcarem o contexto narrativo com as particularidades das personagens. Isso só é possível porque o narrador circula no espaço/texto marcado por frases e parágrafos curtos, contemplando fidedignamente os 
Pontos de Interrogação, v. 3, n. 1, jan./jul. 2013

Revista do Programa de Pós-Graduação em Crítica Cultural

Universidade do Estado da Bahia (UNEB), Campus II - Alagoinhas - BA

dados biográficos e imaginários das mulheres protagonistas. Aliás, a obra, às vezes, dá-nos a impressão de que cada uma das escritoras está inserida em seu próprio palco teatral ou em um cenário fílmico, no qual elas encenariam suas relações humanas. A escritora, que é roteirista, parece utilizar os recursos cinematográficos para imitar a imagem visual de cinema. Diríamos que a contribuição para a realização dessa técnica, na obra Vésperas, são os parágrafos e os períodos curtos, os quais possibilitam maior agilidade e efeito nas cenas narradas.

É pertinente esclarecer que o nosso interesse não é fazer uma aproximação da escrita ficcional lunardiana e das biografias das mulheres escritoras, com o intuito de apurar a história verídica de cada uma das personagens. O que se pretende, com esta análise, é pontuar o quanto o texto literário é tecido por um emaranhado de vozes que se encontram no limite da angústia interior das Vésperas, permitindo que o literário e o biográfico se cruzem no espaço mimético da escrita ficcional.

Dessa maneira, aos olhos do leitor/expectador, é possível perceber, entre as personagens Virginia Woolf e Clarice Lispector, contrapontos importantes que, coincidentemente, são encenados por mulheres artistas/atrizes/protagonistas no palco de um mundo biográfico, literário e ficcional. São mulheres escritoras, de família tradicional, que viveram em um contexto histórico marcado pelas desavenças de gêneros em uma sociedade patriarcal. A primeira, Virginia Woolf, uma escritora bem sucedida, mundialmente conhecida por suas ideias feministas, aclamada e admirada pela crítica e pelos leitores. Uma mulher à frente do seu tempo, que lutou tenazmente contra o preconceito e a opressão sofridos pelas mulheres. Nasceu em $1882^{7}$, em Londres, em uma família aristocrática de escritores e de advogados. Na sua juventude, Virginia Woolf sofreu constantes crises; em março de 1941, a romancista se vestiu com um casaco, encheu os bolsos de pedras e suicidou-se em um rio próximo da sua casa. Nas palavras de Adriana Lunardi, Virginia:

Tira do armário o casaco de lã sete oitavos e enfia os braços nas mangas. Abotoa-se até a gola e mergulha as mãos, conferindo a profundidade dos bolsos em faca. A mão, tateante como se estivesse no escuro, procura a bengala e não a encontra. É preciso erguer-se, desta vez sem ajuda. Virginia acomoda outra vez a pedra no bolso do casaco já sujo e encharcado. O peso agora é ainda maior e ela só tem a si para recomeçar. Ela nada, despreocupada como um peixe. Suas braçadas

7 Para saber mais, veja Maud Mannoni, em Elas não sabem o que dizem: Virginia Woolf, as mulheres e a psicanálise (1999). 
largas ceifam camadas e camadas de água, até alcançar a correnteza do rio, onde a pedra no bolso não faz a menor diferença (LUNARDI, 2002, p. 13; 16; 19).

A água é um elemento que sempre fascinou Virginia Woolf. Segundo Maud Mannoni, em Elas não sabem o que dizem: Virginia Woolf, as mulheres e a psicanálise (1999, p. 15), Virginia expressa o "drama de existir num fascínio pela água, que poderia tragar os corpos, acalentá-los”. A simbologia da água, segundo o Dicionário de Símbolos, pode se referir à fonte da vida, meio de purificação e centro de regenerescência. As águas, representando a "infinidade dos possíveis”, contêm o germe dos germes: “Mergulhar nas águas, para delas sair sem se dissolver totalmente, salvo por uma morte simbólica, é retornar às origens, carregar-se, de novo num imenso reservatório de energia e nele beber uma força nova: fase passageira de regressão e desintegração” (CHEVALIER; GHEERBRANT, 1997, p. 15).

Nota-se que, assim como Virginia Woolf, Adriana Lunardi também mergulha nas águas que representam a infinitude para descobrir e para resgatar a simbologia da eternidade, a qual transparece nas vozes reminiscentes do texto. São vozes que ecoam nas dimensões da memória, enunciando o prelúdio da morte, um artifício que conduz o corpo a um padecimento transitório. As vozes ocupam também o eixo da travessia e, paradoxalmente, murmuram no êxtase do inconsciente, ignorando os limites do próprio corpo. Para Adriana Lunardi (2002, p. 1819):

O esforço desesperado de Virginia ignora as reações do corpo. As vozes não permitem que ela calcule seus avanços. É como um sonho ruim, em que se sente correr sem sair do lugar. Todo começo é assim, disso ela sabia. Os contos, os romances, as cartas. Sofria o mesmo terror de não conseguir. O fim sempre fora mais fácil, chegava com a naturalidade com que chegam todos os finais de história, anunciando-se pouco a pouco até que tudo concordasse. Na vida, é diferente, como não tinha de ser. Virginia decide então lançar de vez o corpo às águas, que já lhe cobrem as pernas, fugindo aos pássaros, aos pensamentos, ao peso da descoberta.

O que se sobressai nessa passagem é a condição de lidar com as dores da vivência humana. O sentido da vida é ameaçado pela culpa e pelo ressentimento de negar a si mesma; por isso, resolve buscar o caminho da finitude, ou seja, um caminho para uma nova descoberta. São caminhos que ultrapassaram os limites da condição humana, enunciando o fim do tédio, dos conflitos, dos desequilíbrios emocionais recorrentes na vida de Virginia Woolf.

Em ensaio intitulado Um teto todo seu (1928), na parte “A autora e sua obra”, notificase que Virginia Woolf, atormentada e "vivendo em meio a uma série de crises de depressão, tentou o suicídio três vezes” (WOOLF, s.d., p. 139). Na ocasião da sua morte, deixou um bi- 
lhete às margens do rio, junto a um chapéu e a uma bengala; nele, estava escrito: "Tenho a impressão de que vou ficar louca. Ouço vozes e não posso concentrar-me no trabalho. Lutei, mas não posso continuar; sinto que as vozes e os fantasmas habitaram o palco da minha existência” (WOOLF, s.d., p. 141). Contudo, pode-se dizer que, com "todas as terríveis dificuldades que enfrentou não puderam impedi-la de exercer seu poder criativo e construir uma das obras mais inovadoras do século XX” (Idem, p. 139).

A segunda escritora, Clarice Lispector, cuja vida é ficcionalizada, é filha de emigrantes russos, naturalizada brasileira, e passou a infância no Recife, onde cursou os estudos primários e os secundários. Em 1929, transfere sua residência para o Rio de Janeiro, graduando-se em Direito. Assim como Virginia Woolf, Clarice Lispector é uma escritora renomada pela crítica literária mundial, mas que se declarava uma pessoa insegura, indecisa, medrosa e sem rumo na vida (BORELLI, 1988).

Marilda Corrêa Ceribelli, em Mulheres singulares e plurais (sofrimento e criatividade) (2006), trata de questões relacionadas à história de vida de oito personalidades femininas, expondo os seus sentimentos humanos: amor, ódio, equilíbrio e loucura. Segundo a historiadora, para conseguir entender Clarice, é necessário ir além do explicitado na sua escrita e ler nas entrelinhas de seus textos, "porque suas entrelinhas falam, e como falam!” (CERIBELLI, 2006, p. 70). Passamos a penetrar no seu “coração selvagem” e a sentir seu mundo de desejos e de fantasias, ocultos em sua escrita enigmática (Idem, p. 70); uma escrita sensível, experiente, fascinante, psicológica e subjetiva.

É através da escritura literária que Clarice desfaz os nós dos seus mistérios; nós que, muitas vezes, podem ser observados pelos reflexos da tessitura ficcional. Não pretendemos, assim como Marilda Corrêa Ceribelli (2006, p. 70):

[...] decifrar seu enigma: o Mito Clarice. Queremos apenas desmitificar alguns elementos negativos que compõem sua imagem de mulher fria, impessoal, distante, antipática. Imagem que, se diga a verdade, muitas vezes, foi construída por ela própria. O mito é ao mesmo tempo negativo e positivo, Clarice não fugiu à regra, razão pela qual seu discurso mítico oferece grande atração aos leitores $^{8}$.

8 Conforme Marilda Corrêa Ceribelli (2006, p. 70), a "palavra mito tem um duplo significado, é ambíguo, permite diferentes olhares. Seu caráter dicotômico, vindo da Grécia Clássica, ainda é o mesmo na atualidade; 
As imagens descritas no fragmento acima revelam a escritora Clarice Lispector como uma “mulher fria”, “distante” e “antipática”. Isso evidencia, por um lado, um discurso que censura e que desmitifica a imagem grandiosa do mito clariciano, mas, por outro, conforme Ceribelli: “aponta para uma mulher sensível, amorosa, corajosa, singular complexa, apaixonada, única. [...] O fato de ser Clarice [...] tornou mais desafiador seu estudo, pela ambiguidade que revela pelo jogo de antíteses entre o eu e o não eu, entre o ser e o não ser” (CERIBELLI, 2006, p. 70). Outrora, essas imagens podem ser reduplicadas e transportadas para outros textos, sendo uma espécie de simulacro do eu autoral que se constitui em um contexto, formando intertexto na dobra de outros textos. Em Vésperas, sobretudo, Clarice afirma que:

Em minha cabeça, nada se acomodava. Os pensamentos fogem antes que eu possa esclarecê-los. [...] Mas um pouco de violência faz parte de mim. Uso unhas afiadas sempre que me põem contra a parede. A cicatriz discreta, mas indelével, na pálpebra esquerda da Cris, coleguinha de maternal, é testemunha do meu estilo. Desde que me alfabetizei, contudo, transferi essa ferocidade para as palavras, que cicatrizam mais lentamente que os arranhões (LUNARDI, 2002, p. 66).

Percebe-se, aqui, uma Clarice atormentada, que transfere a sua violência e a sua ferocidade para a arte da escrita. Podemos observar que esta Clarice lunardiana pode ser (con)fundida com a personagem Joana, da primeira obra de Clarice Lispector, Perto do coração selvagem (1944). Para Deise Bastos da Costa (2010, p. 24), o “romance Perto do coração selvagem (1980), dada a recorrência na narrativa lunardiana de certos motivos ou temas muito frequentes no discurso de Clarice Lispector, aparece enquanto o principal intertexto”.

A história da personagem Joana é marcada pelo enigma da morte, assim como as histórias das personagens lunardianas. No conto “Clarice”, a personagem só conheceu o pai na adolescência, quando a mãe estava prestes a morrer; já Joana, ao contrário de Clarice, conviveu com o pai, perdendo a mãe na infância; depois, perde também o pai; órfã, vai morar com os tios. Além desses aspectos, percebe-se que, em “Clarice”, o texto é marcado por uma série de coincidências que se associam a dados biográficos e também à obra de Clarice Lispector, como, por exemplo, os nomes dos personagens Otávio e Clarice e o título da obra.

quando positivo significa o que é verdadeiro e quando negativo representa algo fantástico, enganoso, falso. Clarice é mito positivo e negativo”. 
Bernadete Pasold, em “Temas narrativos nos romances de Virginia Woolf e Clarice Lispector” (1985), conclui, sobre os estudos comparados nos romances de Clarice Lispector e de Virginia Woolf, que a morte está presente na ficção das autoras, mas o tratamento dado por elas não é o mesmo:

\footnotetext{
Embora ambas consideram (sic) a morte um incidente de vida, Clarice Lispector vê a morte sob um ponto de vista solitário; suas personagens pensam sempre na própria morte. Virginia Woolf apresenta outros aspectos da morte [...] além da extinção física: a morte de uma amizade, pela mudança, e a morte da mente, pela ausência de mudança, como se pode ver em The Years. Assim, para a escritora inglesa a morte tem mais implicações do que para a escritora brasileira. (PASOLD, 1985, p. 822).
}

A morte, que está presente na ficção das autoras Clarice e Virginia, está também presente em Vésperas; é a morte literária de cada personagem. Mas a morte, em Adriana Lunardi, parece ser contemplada por um aprisionamento misterioso, confuso e doentio. A morte ceifa, de uma maneira sutil, paradoxal, insinuando um mundo confuso de vozes que balbuciam no exílio solitário das personagens. É a morte do silêncio literário que anula a morte física, esvaziando a dor e a tortura em busca de uma cura ilusória. É a morte mórbida, de quem sofreu um profundo desamparo e uma amarga decepção da vida. Essa é a morte transitória das Vésperas, que abandonam as vozes para dialogar com o mundo do além e do indizível da palavra escrita. Uma escrita que limita o tempo da morte; a escrita imutável das Vésperas, das ruínas, da velhice e da decadência das personagens escritoras.

\section{REFERÊNCIAS}

BORELLI, Olga. A difícil definição. In: LISPECTOR, Clarice. A paixão segundo G. H. Edição crítica. Coord. Benedito Nunes. Florianópolis: Ed. UFSC, 1988. Disponível em: <http://books.google.com.br/books?id=LnueC7NGnnEC\&pg=PA353\&lpg=PA353\&dq=bern adete+pasold+UFSC+>. Acesso em: 10 out. 2012.

BORGES, Telma. Literatura brasileira - modernidade e tendências contemporâneas. Montes Claros: CEAD UNIMONTES, 2004. (Caderno Didático). Disponível em: <www.cead.unimontes.br/.../literaturabrasileiramodernidade/.../searcht....>. Acesso em: 10 jun. 2012.

BRANCO, Lúcia Castello; BRANDÃO, Ruth Silviano. A mulher escritora. Rio de Janeiro: Lamparina Ed., 2004.

CERIBELLI, Marilda Corrêa. Mulheres singulares e plurais: (sofrimento e criatividade). Rio de Janeiro: 7 Letras, 2006. 
CHEVALIER, Jean; GHEERBRANT, Alain. Dicionário de símbolos: mitos, sonhos, costumes, gestos, formas, figuras, cores, números. Trad. Vera Costa e Silva. Rio de Janeiro: J. Olympio, 2005.

COSTA, Deise Bastos da. Figurações da mulher-artista nos contos de Adriana Lunardi. 2010. Dissertação (Mestrado em Letras) — Instituto de Letras e Artes, Universidade Federal do Rio Grande, Rio Grande, 2010. Disponível: <http://www.ppgletras.furg.br/disserta/dei sebastos.pdf>. Acesso em: 24 fev. 2012.

FRANCO, Adenize. Às vésperas do fim: um passeio pela narrativa contemporânea de Adriana Lunardi. Temas \& Matizes, Cascavel, v. 5, n. 9, 2006. Disponível em: <http://www.unioeste.br/saber>. Acesso em: 11 mar. 2012.

GENETTE, Gerárd. Paratextos editoriais. Trad. Álvaro Faleiros. São Paulo: Ateliê, 2009.

HOUAISS, Antônio; VILLAR, Mouro Sales. Dicionário Houaiss da Língua Portuguesa. Rio de Janeiro: Objetiva, 2004.

LUNARDI, Adriana. Marujo ao mar. Curitiba: Rascunho, o jornal de literatura do Brasil, jan 2012. Entrevista concedida a Rogério Pereira e Yasmin Taketani. Disponível em: <http://rascunho.gazetadopovo.com.br/marujo-ao-mar/>. Acesso em: 28 dez. 2011.

LUNARDI, Adriana. Vésperas. Rio de Janeiro: Rocco, 2002.

MANNONI, Maud. Elas não sabem o que dizem: Virginia Woolf, as mulheres e a psicanálise. Trad. Lucy Magalhães. Rio de Janeiro: J. Zahar, 1999.

NEPOMUCENO, Luis André. O eu e o mundo nas cartas de Emily Dickinson. In: ARRUDA, Aline Alves et al. (Org.). A escritura no feminino: aproximações. Belo Horizonte: UFMG, 2011.

PASOLD, Bernadete. Temas narrativas nos romances de Virginia Woolf e Clarice Lispector. 1985. Tese (Doutorado) — Universidade Federal de São Paulo, São Paulo ,1985.

RODRIGUES, Carla. Nove escritoras a beira da morte. In: LUNARDI, Adriana. Home Page. Desenvolvido por Ricardo Mayer, s/d. Apresenta a biografia e a bibliografia da autora Adriana Lunardi. Disponível em: <http://www.adrianalunardi.com.br/XHTML/resenhas.php?re Codigo=24>. Acesso em: 12 dez. 2011.

WOOLF, Virginia. Um teto todo seu. Trad. Vera Ribeiro. São Paulo: Círculo do Livro, s.d. Disponível em: <http://virginiawoolf.files.wordpress.com/2012/03/um-teto-todo-seu-virginiawoolf.pdf>. Acesso em: 3 out. 2012.

Recebido em: 20 de junho de 2013.

Aceito em: 30 de agosto de 2013. 